\title{
3-Dichloroacetyl oxazolidine protect maize from imazethapyr herbicide injury
}

Li-Xia Zhao ${ }^{1}$, Hao Wu ${ }^{1}$, Ying Fu ${ }^{1}$, Yue-Li Zou ${ }^{1}$, and Fei Ye ${ }^{{ }^{*}}$

\section{ABSTRACT}

Safeners are an important tool used to ensure the safe using of herbicide. The objective of this paper was to investigate the protective effect of four 3-dichloroacetyl oxazolidine safeners (3-dichloroacetyl-2,2-dimethyl-1,3-oxazolidine [R-28725], racemate of 3-dichloroacetyl-2,2-dimethyl-4ethyl-1,3-oxazolidine, and its two chiral stereoisomers) in reducing the injury caused by imazethapyr. Physiological and biochemical tests were conducted under laboratory condition, by using seed treatment with safeners and soil treatment with imazethapyr, respectively. The interaction of two safeners (R-28725 and $R$-stereoisomer) and imazethapyr reduced the injury of maize significantly, and also increased glutathione content, activity of glutathione $S$-transferases, and activity of acetolactate synthase in maize. When induced by $R$-stereoisomer, the GSH content in root and in shoot increased $100.7 \%$ and $73.6 \%$, respectively. When induced by $\mathrm{R}-28725$, the GST activity in vivo increased threefold and the GST activity in vitro more than doubled. The kinetic parameter $V_{\max }$ of GST in the maize treated with $\mathrm{R}-28725$ and $R$-stereoisomer increased by $102.2 \%$ and $81.9 \%$, respectively, compared with the control. The results also showed that R-28725 and $R$-stereoisomer induced glutathione $S$-transferases affinity for the substrate of conjugation reaction significantly.

Key words: 3-Dichloroacetyl oxazolidine, biological activity, GST activity, GST affinity, Zea mays.

${ }^{1}$ Northeast Agricultural University, College of Science, Harbin, Heilongjiang Province, 150030, China.

*Corresponding author (yefei@neau.edu.cn).

Received: 9 September 2015.

Accepted: 27 January 2016.

doi:10.4067/S0718-58392016000200004

\section{INTRODUCTION}

Imazethapyr [ $(R S)$-5-ethyl-2-(4-isopropyl-4-methyl-5-oxo-2imidazolin-2-yl)nicotinic acid], an imidazolinone herbicide, was discovered in the 1980s. Imazethapyr controls weeds by inhibiting the activity of acetolactate synthase (ALS) which catalyzes the first step in the biosynthesis of valine, leucine and isoleucine (Maja and Branko, 2011). Imazethapyr has been used worldwide in weed control. As a consequence, phytotoxic effects to certain rotational crops were observed because of imazethapyr residue in cultivation soil and weed resistance to imazethapyr has developed into a more serious problem (Zhou et al., 2009; Pinto et al., 2009; Heap, 2014).

Herbicide safeners are a group of synthetic compounds that could protect selected plants against herbicide injury without decreasing herbicidal activity to target weeds (Kraehmer et al., 2014). In 1947, Hoffman realized that safener was a useful tool to protect crop from herbicide injury. Nearly 20 safeners has subsequently been developed and commercialized by famous agrochemical companies (Jablonkai, 2013). While the exact mechanism of safener is still not completely understood, it seems that safeners could increase crop tolerance by inducing the activity of detoxifying enzyme glutathione $S$-transferases (GST) and content of glutathione (GSH) involved in detoxification of exogenous compounds (Del Buono and Ioli, 2011; Matola and Jablonkai, 2007). GST are multifunctional enzymes which catalyze conjugation of GSH with herbicide molecules such as some sulfonylureas, diphenylethers, sulfonamides (Hatzios, 2001; Cummins et al., 2011). Therefore, a possible mechanism was safeners increased the metabolic regulation of herbicide to inactive metabolites in the safened plant (Liu et al., 2009). The speed and effect of detoxification was closely related with the level of activity of GST and content of GSH.

R-28725 (3-dichloroacetyl-2,2-dimethyl-1,3-oxazolidine), a 3-dichloroacetyl oxazolidine derivative, was proven effective in protecting maize (Zea mays L.) from injury by ALS-inhibitor (Davies and Caseley, 1999; Zhao et al., 2014). Racemate of 3-dichloroacetyl-2,2-dimethyl-4-ethyl-1,3-oxazolidine, an analogue of R-28725, has one chiral C atom bonded to four different groups. Chirality is one of the most important properties of molecule because there is always one stereoisomer of chiral molecule exist in living creatures. While one stereoisomer may has some good properties, the other one can be toxic. So, these two stereoisomers which have different configurations may differ in their detoxification ability due to their chirality. However, little work has been done on the different detoxification ability of 
chiral safener. In order to reduce the amount of pesticides used and avoid the possible injury to plant caused by the unnecessary stereoisomers, it is of necessity to develop chiral safeners. In this study, two stereoisomers and the racemate of 3-dichloroacetyl-2,2-dimethyl-4-ethyl-1,3oxazolidine and R-28725 have been evaluated for bioactivity as safener of imazethapyr. Hence, the purpose of this article was to examine the protective effect of R-28725 and chiral 3-dichloroacetyl oxazolidine safeners and further discover the important role of GSH, GST, and ALS in detoxification process through physiological and biochemical tests.

\section{MATERIALS AND METHODS}

\section{Materials and chemical reagents}

The tested soil was Mollisols-cryolls clay loam type and collected from the Northeast Agricultural University Horticulture Station with a $\mathrm{pH}$ of 7.37. The seedlings of maize (Zea mays L.) 'Dongnong 253' were germinated and raised in a growth chamber at the Pesticide Chemistry Laboratory, Northeast Agricultural University. Imazethapyr (98.5\%, wettable powder) was obtained from Aladdin Chemistry (Shanghai, China). R-28725, racemate of 3-dichloroacetyl-2,2-dimethyl-4-ethyl-1,3-oxazolidine and its two stereoisomers ( $R$-enantiomer: $(R)$-3-dichloroacetyl2,2-dimethyl-4-ethyl-1,3-oxazolidine and $S$-enantiomer: (S)-3-dichloroacetyl-2,2-dimethyl-4-ethyl-1,3-oxazolidine) were synthesized in our laboratories $(99.0 \%)$ (Table 1).

\section{Growth conditions}

Seedlings of maize were soaking in solutions of safeners ( 0 , $1,5,10,25,50$, and $100 \mathrm{mg} \mathrm{kg}^{-1}$ ) for $12 \mathrm{~h}$, the control was soaking in water. Then, seeds were germinated in dishes in a growth chamber for $24 \mathrm{~h}$. After seeds were sown in papercups $(10 \mathrm{~cm} \times 15 \mathrm{~cm})$, seven seeds per cup, containing soil added with imazethapyr $\left(0.5 \mathrm{mg} \mathrm{kg}^{-1}\right)$ with a depth of 13 $\mathrm{cm}$, maize seeds were incubated in a growth chamber with a $12: 12 \mathrm{~h}$ photoperiod, $26.5 \pm 1{ }^{\circ} \mathrm{C}$ temperature, and $75 \%$ relative humidity. Each treatment was replicated three times.

The recovery rate of growth index (plant height, root length, fresh weight of shoot, fresh weight of root) of maize was measured $7 \mathrm{~d}$ after treatment and expressed as percentage:

Growth index of maize treated by safener and herbicide-Growth index of Recovery rate $(\%)=\frac{\text { maize treated by herbicide }}{\text { Growth index of maize untreated- }}$ Growth index of maize treated by herbicide

where safeners were R-28725, racemate, and its two optically active enantiomers, and herbicide is imazethapyr.

All tissues of maize were washed and collected for subsequent biological activity assays (GSH, ALS, and GST).
Table 1. Safener chemical names used for test.

\begin{tabular}{ll}
\hline Safener & \multicolumn{1}{c}{ Chemical name } \\
R-28725 & 3-dichloroacetyl-2,2-dimethyl-1,3-oxazolidine \\
$R$-stereoisomer & $(R)$-3-dichloroacetyl-2,2-dimethyl-4-ethyl-1,3-oxazolidine \\
$S$-stereoisomer & $(S)$-3-dichloroacetyl-2,2-dimethyl-4-ethyl-1,3-oxazolidine \\
Racemate & $(R S)$-3-dichloroacetyl-2,2-dimethyl-4-ethyl-1,3-oxazolidine \\
\hline
\end{tabular}

\section{Determination of GSH content, and GST activity}

For determination of GSH content, $0.2 \mathrm{~g}$ tissue of maize (root or shoot) was homogenized in 5\% sulfosalicylic acid and centrifuged at $15000 \mathrm{~g}$ for $20 \mathrm{~min}$. The supernatant was used for GSH content measurements by adding potassium phosphate buffer $(\mathrm{pH}=8.0)$ and DTNB as the chromogenic agent. Absorbance was determined at $412 \mathrm{~nm}$, whereas GSH content was calculated through comparison with a known concentration (Ismaiel and Papenbrock, 2014).

The extraction and GST assay were performed as described by Matola and Jablonkai (2007). The GST activity was obtained by measuring the amount of conjugate constituted from GSH and substrate CDNB and expressed as amount of conjugate per minute per milligram of protein

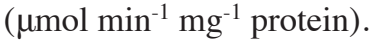

To determine the GST activity in vitro (GST activity against imazethapyr in this study), the amount of imazethapyr was determined by high performance liquid chromatography (HPLC) as described previously (Scarponi et al., 2006). GST enzyme was extracted from root of maize, and added with glutathione and imazethapyr solution. After $2 \mathrm{~h}$ cultivation, residues of imazethapyr in this mixture was measured through HPLC. The GST activity in vitro was expressed as amount of imazethapyr consumed per minute per milligram of enzyme (nmol min-1 $\mathrm{mg}^{-1}$ protein).

\section{Determination of kinetic parameters of GST (CDNB)}

The procedure described by Scarponi et al. (2006) was followed for measuring kinetic parameters of GST with modification. The kinetic parameters maximal rate of reaction $\left(V_{\max }\right)$ and the substrate concentration which results in onehalf the maximum velocity $\left(K_{\mathrm{M}}\right)$ of GST were measured by linear regression of a double reciprocal plot. The kinetic parameters was determined by measuring GST activity over a range of CDNB concentration (0.13-4.14 $\mathrm{mM}$ ) at a single GSH concentration of $5 \mathrm{mM}$.

\section{Determination of ALS activity}

To investigate the effect of safener to target enzyme, ALS activity was determined as described previously (Malkawi et al., 2003). ALS activity was expressed as amount of acetoin composed from acetolactate catalyzed by ALS per hour per milligram of enzyme ( $\mathrm{nmol} \mathrm{h}^{-1} \mathrm{mg}^{-1}$ protein). 


\section{Statistical analysis}

Statistical Product and Service Solutions software (SPSS 16.0, IBM Corporation, Armonk, New York, USA) was used to determine statistical significance at $95 \%$ confidence level $(\mathrm{p}=0.05)$. Data were expressed as mean \pm standard deviation $(\mathrm{n}=3)$.

\section{RESULTS AND DISCUSSION}

\section{Growth level of maize}

The imazethapyr applied to maize at $0.5 \mathrm{mg} \mathrm{kg}^{-1}$ in soil reduced plant height $31.61 \%$, root length $31.90 \%$, fresh weight of shoot $35.72 \%$, and fresh weight of root $33.54 \%$ compared with the control, respectively.
In order to investigate the protective effect of these safeners, R-28725, $R$-stereoisomer, $S$-stereoisomer, and racemate were used to test their protective ability at different concentrations. Growth level of maize were increased by safener application: the recovery rate of maize ranged from $5.53 \%$ to $95.98 \%$. The recovery rate of maize treated by $\mathrm{R}-28725, R$-stereoisomer were significantly higher than other safeners. At the same time, difference of recovery rate of maize treated by different concentration of safeners were observed, and safeners at too high or too low concentration caused decrease of protective effects. The optimum working concentration for R-28725, $R$-stereoisomer, $S$-stereoisomer, racemate were $25,25,25-50$, and $50 \mathrm{mg} \mathrm{kg}^{-1}$, respectively (Figure 1). The optimum recovery rates for four safeners were then applied to physiological and biochemical tests and all subsequent testing were based on this observation.

Figure 1. Recovery rate of growth level of maize treated by imazethapyr and different safeners.

Effect of plant height of maize treated by imazethapyr and different safeners

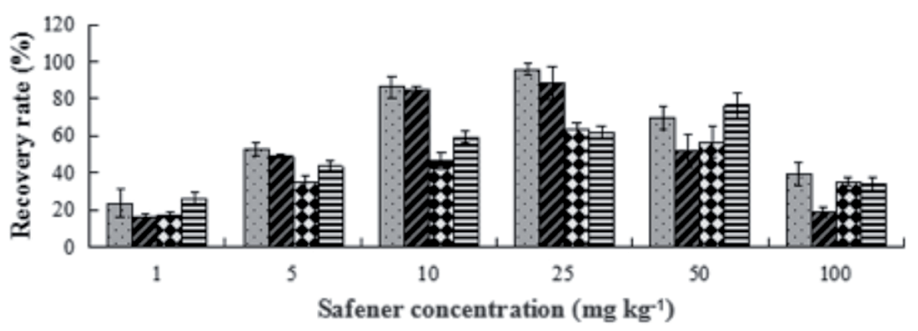

Effect of root length of maize treated by imazethapyr and different safeners

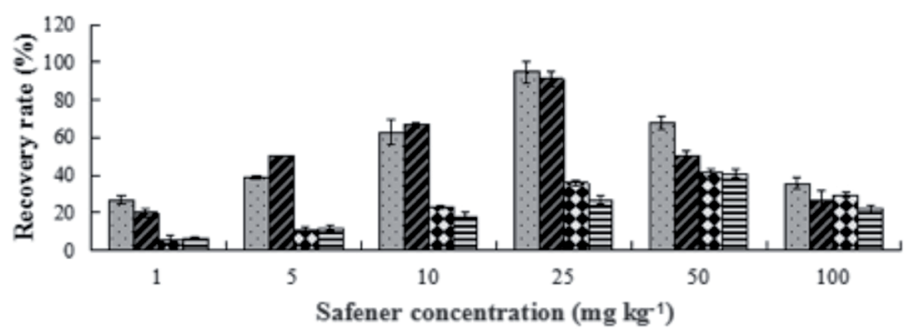

Effect of fresh weight of shoot of maize treated by imazethapyr and different safeners

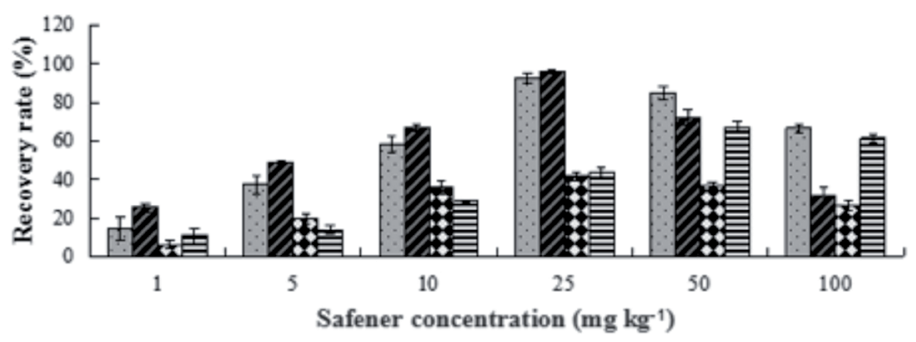

Effect of fresh weight of root of maize treated by imazethapyr and different safeners

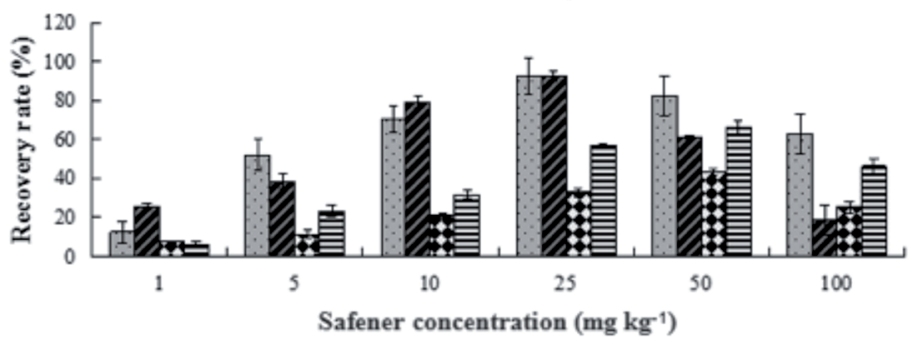




\section{GSH content}

The content of GSH in maize is essential for detoxication of herbicide, depending on the mechanism of safeners. The results indicated that GSH content of maize treated by imazethapyr was elevated. Treated by the combination of safeners and imazethapyr accumulated high GSH content and specific combination of safener and imazethapyr were beneficial (Table 2). The GSH content of maize treated by R-28725 or $R$-stereoisomer combined with imazethapyr was significantly increased compared with the maize treated by imazethapyr.

\section{GST activity}

The interaction between seed treatment with safeners and the application of imazethapyr in soil were investigated. GST activity of maize treated by safeners and imazethapyr were tested to check its important role in detoxification process of imazethapyr. The GST activity of maize showed significant increases in response to $R$-stereoisomer and R-28725, while weak increases were observed in response to $S$-stereoisomer and racemate. In particular, the application of R-28725 and imazethapyr increased GST activity in vivo by $144.20 \%$ and the application of $R$-stereoisomer and imazethapyr increased GST activity in vitro by $40.22 \%$ (Table 3 ). These findings are in agreement with an earlier report (Benekos et al., 2010).

To confirm these results, a measurement of kinetic parameters of GST were conducted to clarify the innate character of the inducement and dynamics of GST.

\section{Kinetic parameters of GST}

In order to obtain more information about the effect of safeners and imazethapyr to GST, the kinetic parameters of GST were investigated. The $V_{\max }$ and $K_{\mathrm{M}}$ values are

Table 2. Effect of safeners and imazethapyr on glutathione (GSH) content of maize.

\begin{tabular}{|c|c|c|}
\hline Treatment & $\begin{array}{l}\text { GSH content } \\
\text { in root }\end{array}$ & $\begin{array}{l}\text { GSH content } \\
\text { in shoot }\end{array}$ \\
\hline & \multicolumn{2}{|c|}{$\longrightarrow \mu \mathrm{g} \mathrm{g}^{-1}$} \\
\hline Control & $5.238 \pm 0.1940 \mathrm{~d}$ & $11.703 \pm 0.1390 d$ \\
\hline Imazethapyr & $6.749 \pm 0.1657 c$ & $14.354 \pm 0.1940 c$ \\
\hline$R$-Stereoisomer+imazethapyr & $10.515 \pm 0.1571 \mathrm{a}$ & $20.312 \pm 0.2721 a$ \\
\hline$S$-Stereoisomer+imazethapyr & $8.111 \pm 0.1619 b$ & $14.962 \pm 0.2767 c$ \\
\hline Racemate+imazethapyr & $9.806 \pm 0.2902 \mathrm{ab}$ & $17.623 \pm 0.2626 b$ \\
\hline R-28725+imazethapyr & $10.183 \pm 0.1940 \mathrm{a}$ & $19.971 \pm 0.2875 a$ \\
\hline
\end{tabular}

Mean \pm standard deviation of three replicates. Values with similar letter in the same volume are not significantly different $(\mathrm{p}>0.05)$. shown in Table 4; $V_{\max }$ values of GST for maize treated by R-28725 and $R$-stereoisomer were significantly increased, indicating the strong inducement of GST caused by safeners. $K_{\mathrm{M}}$ values of GST were notably decreased by R-28725 and $R$-stereoisomer treatment, indicating that R-28725 and $R$-stereoisomer increased the affinity of GST to substrate of GSH conjugated reaction. This increased GST affinity is an advantage to the process of detoxication.

\section{ALS activity}

As imazethapyr was a strong ALS inhibitor, we attempted to study the effect of safeners and imazethapyr on the ALS activity and investigate the protective effectiveness of safeners (Table 5).

The results showed that ALS activity was significantly inhibited by imazethapyr compared with the untreated control. Treatment of maize with safeners alone did not induce a significant change in the ALS activity compared with the untreated control. In contrast to other investigated safeners, R-28725 and $R$-stereoisomer almost reversed the

Table 4. Effect of safeners and imazethapyr on kinetic parameters of maize glutathione $S$-transferases (GST).

\begin{tabular}{lcc}
\hline Treatment & $V_{\max }$ & $K_{\mathrm{m}}$ \\
\hline & $\mathrm{nmol} \mathrm{\textrm {min } ^ { - 1 } \mathrm { mg } ^ { - 1 } \text { protein }}$ & $\mathrm{mmol} \mathrm{L}^{-1}$ \\
Control & $0.790 \pm 0.030 \mathrm{e}$ & $1.950 \pm 0.056 \mathrm{~b}$ \\
Imazethapyr & $0.417 \pm 0.031 \mathrm{f}$ & $3.987 \pm 0.151 \mathrm{a}$ \\
$R$-stereoisomer & $1.437 \pm 0.023 \mathrm{~b}$ & $1.320 \pm 0.010 \mathrm{~d}$ \\
$S$-stereoisomer & $0.913 \pm 0.067 \mathrm{~d}$ & $1.673 \pm 0.057 \mathrm{c}$ \\
Racemate & $1.090 \pm 0.035 \mathrm{c}$ & $1.570 \pm 0.017 \mathrm{c}$ \\
R-28725 & $1.597 \pm 0.091 \mathrm{a}$ & $1.167 \pm 0.144 \mathrm{~d}$ \\
\hline
\end{tabular}

Mean \pm standard deviation of three replicates. Values with similar letter in the same volume are not significantly different $(\mathrm{p}>0.05)$.

Table 5. Effect of safeners and imazethapyr on acetolactate synthase (ALS) activity of maize.

\begin{tabular}{|c|c|}
\hline Treatment & ALS Activity \\
\hline & $\mathrm{nmol} \mathrm{h}^{-1} \mathrm{mg}^{-1}$ protein \\
\hline Control & $0.093 \pm 0.0022 \mathrm{a}$ \\
\hline Imazethapyr & $0.039 \pm 0.0015 d$ \\
\hline$R$-stereoisomer & $0.081 \pm 0.0025 a$ \\
\hline$S$-stereoisomer & $0.092 \pm 0.0017 \mathrm{a}$ \\
\hline Racemate & $0.078 \pm 0.0032 \mathrm{a}$ \\
\hline $\mathrm{R}-28725$ & $0.094 \pm 0.0051 \mathrm{a}$ \\
\hline$R$-stereoisomer + imazethapyr & $0.075 \pm 0.0031 b$ \\
\hline$S$-stereoisomer + imazethapyr & $0.048 \pm 0.0041 \mathrm{~d}$ \\
\hline Racemate + imazethapyr & $0.062 \pm 0.0007 \mathrm{c}$ \\
\hline R-28725 + imazethapyr & $0.085 \pm 0.0028 \mathrm{a}$ \\
\hline
\end{tabular}

Mean \pm standard deviation of three replicates. Values with similar letter in the same volume are not significantly different $(\mathrm{p}>0.05)$.

Table 3. Effect of safeners and imazethapyr on glutathione $S$-transferases (GST) activity of maize.

\begin{tabular}{|c|c|c|c|}
\hline \multirow[b]{2}{*}{ Treatment } & \multirow{2}{*}{$\frac{\text { GST activity in vivo }}{\mu \mathrm{mol} \mathrm{min}^{-1} \mathrm{mg}^{-1} \text { protein }}$} & \multirow[b]{2}{*}{ Treatment } & \multirow{2}{*}{$\begin{array}{l}\text { GST activity in vitro } \\
\text { nmol } \mathrm{min}^{-1} \mathrm{mg}^{-1} \text { proteir }\end{array}$} \\
\hline & & & \\
\hline Control & $2.95 \pm 0.136 f$ & Control & $2.36 \pm 1.514 \mathrm{e}$ \\
\hline Imazethapyr & $4.05 \pm 0.278 \mathrm{e}$ & Imazethapyr & $4.60 \pm 0.300 c$ \\
\hline$R$-Stereoisomer + imazethapyr & $8.31 \pm 0.269 b$ & $R$-Stereoisomer & $6.45 \pm 0.601 \mathrm{a}$ \\
\hline$S$-Stereoisomer + imazethapyr & $6.30 \pm 0.159 d$ & $S$-Stereoisomer & $4.30 \pm 0.169 d$ \\
\hline Racemate + imazethapyr & $7.49 \pm 0.184 c$ & Racemate & $4.94 \pm 0.498 c$ \\
\hline R-28725+ imazethapyr & $9.89 \pm 0.484 a$ & R-28725 & $6.32 \pm 0.236 b$ \\
\hline
\end{tabular}

Mean \pm standard deviation of three replicates. Values with similar letter in the same volume are not significantly different $(\mathrm{p}>0.05)$. 
injury caused by imazethapyr. These data could indicate that R-28725 and $R$-stereoisomer can elevate the ALS activity of maize inhibited by imazethapyr significantly.

Imazethapyr, an extensively used herbicide with two enantiomers, causes phytotoxic effects to rotational crops and weed resistance (Yi et al., 2007). In order to extend the use of imazethapyr, it is necessary to develop effective safeners. It has been reported that imazaquin can be detoxified by safener BAS-145138, but there is no report about safeners of imazethapyr with high activity (Loniovereror, 1997). Aiming to develop safener of imazethapyr, the protective effects of four safeners were studied in our laboratory, showing that the maize injured by imazethapyr were effectively protected by $\mathrm{R}-28725$ or $R$-stereoisomer. The seed treatment with safeners $\mathrm{R}-28725$ or $R$-stereoisomer provided complete protection against imazethapyr.

Another aim of our study was to investigate the mechanism of safeners. The results in this study showed that the GSH content, GST activity in vivo, and ALS activity were increased by safeners treatment under laboratory condition, which is in agreement with previous studies (Jablonkai, 2013). Without imazethapyr application, seed treatment with these safeners also promoted the increase of GST activity in vitro and affinity of GST enzyme. Data obtained at this study are corroborate by Scarponi et al. (2006), who reported five safeners significantly changed the kinetic parameters of maize GST. This might suggest that these safeners induce GST activity significantly, increase conjugation of imazethapyr with GSH to some extent, and result in release of target enzyme ALS in maize, finally.

\section{CONCLUSIONS}

According to data obtained in this study, it can be concluded that seed treatment with R-28725 or $R$-stereoisomer present protective ability to injury of maize caused by imazethapyr. This study is the first one on the protective effect of chiral 3-dichloroacetyl oxazolidine and their interaction with imazethapyr. The further studies will focus on the development of structural optimization of $R$-stereoisomer to improve the protective effects.

\section{ACKNOWLEDGEMENTS}

This work was supported by the National Nature Science Foundation of China (31401787, 31572042), China Postdoctoral Science Foundation (2015M571384), Natural Science Foundation of Heilongjiang Province of China (C2015014), and "Young Talents" Project of Northeast Agricultural University (14QC38).

\section{REFERENCES}

Benekos, K., C. Kissoudis, I. Nianiou-Obeidat, N. Labrou, P. Madesis, et al. 2010. Overexpression of a specific soybean GmGSTU4 isoenzyme improves diphenyl ether and chloroacetanilide herbicide tolerance of transgenic tobacco plants. Journal of Biotechnology 150:195-201.
Cummins, I., D.P. Dixon, S. Freitag-Pohl, M. Skipsey, and R. Edwards. 2011. Multiple roles for plant glutathione transferases in xenobiotic detoxification. Drug Metabolism Reviews 43:266-280.

Davies, J., and J.C. Caseley. 1999. Herbicide safeners: a review. Pesticide Science 55:1043-1058.

Del Buono, D., and G. Ioli. 2011. Glutathione S-transferases of Italian ryegrass (Lolium multiflorum): activity toward some chemicals, safener modulation and persistence of atrazine and fluorodifen in the shoots. Journal of Agricultural and Food Chemistry 59:1324-1329.

Hatzios, K.K. 2001. Functions and regulation of plant glutathione S-transferases. p. 218-239. In Hall, J.C., R.E. Hoagland, and R.M. Zablotowicz (eds.) Pesticide biotransformation in plants and microorganisms: Similarities and divergences. American Chemical Society, Washington, DC, USA.

Heap, I. 2014. The international survey of herbicide resistant weeds. Available at http://www.weedscience.org (accessed December 2014).

Ismaiel, A.A., and J. Papenbrock. 2014. The effects of patulin from Penicillium vulpinum on seedling growth, root tip ultrastructure and glutathione content of maize. European Journal of Plant Pathology 139:497-509.

Jablonkai, I. 2013. Herbicide safeners: Effective tools to improve herbicide selectivity. In Andrew Price (ed.) Herbicides-Current research and case studies in use. InTech. doi:10.5772/55168.

Kraehmer, H., B. Laber, C. Rosinger, and A. Schulz. 2014. Herbicides as weed control agents: State of the art. I. Weed control research and safener technology: The path to modern agriculture. Plant Physiology 166:1119-1131.

Liu, J.L., M. Brazier-Hicks, and R. Edwards. 2009. A kinetic model for the metabolism of the herbicide safener fenclorim in Arabidopsis thaliana. Biophysical Chemistry 143:85-94.

Loniovereror, G.L. 1997.Effect of BAS-145138 on the phytotoxicity of imazaquin and chlorimuron-ethyl. Weed Science 47:755-763.

Maja, M., and K. Branko. 2011. Activity of acetolactate synthase (ALS) of redroot pigweed in relation to imazethapyr application. African Journal of Biotechnology 10:9577-9585.

Malkawi, H.I., N.A. Al-Quraan, and W.M. Owais. 2003. Acetolactate synthase activity and chlorsulfuron sensitivity of gamma-irradiated lentil (Lens culinaris Medik.) cultivars. Journal of Agricultural Science 140:83-91.

Matola, T., and I. Jablonkai. 2007. Safening efficacy of halogenated acetals, ketals and amides and relationship between the structure and effect on glutathione and glutathione $S$-transferases in maize. Crop Protection 26:278-284.

Pinto, J J.O., J.A. Noldin, A. Machado, C.F. Pinho, M.D. Rosenthal, A. Donida, et al. 2009. Corn (Zea mays) as bioindicator of the residual activity of (imazethapyr+imazapic). Planta Daninha 27:1005-1014.

Scarponi, L., E. Quagliarini, and D. Del Buono. 2006. Induction of wheat and maize glutathione S-transferase by some herbicide safeners and their effect on enzyme activity against butachlor and terbuthylazine. Pest Management Science 62:927-932.

Yi, F., B. Guo, Z. Peng, H. Li, P. Marriott, and J.M. Lin. 2007. Study of the enantioseparation of imazaquin and enantioselective degradation in field soils by CZE. Electrophoresis 28:2710-2716.

Zhao, L.X., Y. Fu, S. Gao, Z.Y. Xing, L.N. Wei, and F. Ye. 2014. Protective responses induced by 3-dichloroacetyl oxazolidine safeners in maize (Zea mays). International Journal of Agriculture and Biology 16:1204-1208.

Zhou, Q.Y., X. Chao, Y.S. Zhang, and W.P. Liu. 2009. Enantioselectivity in the phytotoxicity of herbicide imazethapyr. Journal of Agricultural and Food Chemistry 57:1624-1631 . 